\title{
Probiotic characteristics of Lactobacillus plantarum strains from traditional butter made from camel milk in arid regions (Sahara) of Algeria
}

\author{
By Kacem Maurad* and Kaid-Harche Meriem**
}

\author{
*Département de Biotechnologie, Faculté des Sciences, \\ Université d'Es-Senia, Oran BP.1524 Oran el M'Naouar 31000, Oran, Algérie \\ kacemmourad1964@yahoo.fr \\ **Laboratoire de Biologie Appliquée, Université d’Oran-Usto, Algérie
}

\section{RESUMEN}

Características probióticas de cepas de LactobaciIlus plantarum de mantequilla tradicional de leche de camello de regiones áridas (Sáhara) de Argelia.

Se evalúan algunas características probióticas de cepas de Lactobacillus plantarum aisladas de la mantequilla tradicional elaborada a partir de leche de camello (shmen). De 38 cepas investigadas para resistencia biliar, 14 fueron tolerantes a un $2 \%$ oxgall con porcentajes de supervivencia entre 69 y 75\%. De éstas, sólo 4 cepas (L. plantarum SH5, SH12, $\mathrm{SH} 24$ and $\mathrm{SH} 32$ ) fueron suficientemente resistentes a $\mathrm{pH} 2$ con periodos de incubación entre 2 y $6 \mathrm{~h}$. Únicamente los extractos crudos de L. plantarum SH12 y L. plantarum $\mathrm{SH} 24$ fueron inhibitorios frente a Lactococcus lactis B8, la cepa utilizada como indicador. La actividad antibacteriana de los extractos crudos se perdió completamente después de tratamiento con $\alpha$-quimotripsina y proteinasa $\mathrm{K}$. Las cepas $\mathrm{SH} 12$ y SH24 fueron susceptibles a la penicilina G, oxacilina, vancomicina y clindamicina, pero resistentes a tetraciclina y kanamicina. Dichas cepas mostraron una rápida actividad acidificante $(0,921$ y $1,075 \mathrm{mmol} / \mathrm{l}$ de ácido láctico, respectivamente), una buena actividad proteolítica (5,45 y $3,49 \mathrm{mg} / \mathrm{l}$ de tirosina a las $72 \mathrm{~h}$, respectivamente) y un alto porcentaje de supervivencia después de liofilización. Ninguna de las cepas produjo polisacáridos o hemolisina en sangre de oveja.

PALABRAS CLAVE: Antibiótico - Bacterias acidolácticas - Bacteriocina - Lactobacillus plantarum - Mantequilla - Probiótico.

\section{SUMMARY}

Probiotic characteristics of Lactobacillus plantarum strains from traditional butter made from camel milk in arid regions (Sahara) of Algeria.

Lactobacillus plantarum strains previously isolated from the traditional butter made from camel milk (shmen) were evaluated for some probiotic criteria. Among 38 strains investigated for bile resistance, 14 were tolerant to $2 \%$ oxgall with survival percentages ranging from 69 to $75 \%$. Out of these, only 4 strains (L. plantarum SH5, SH12, SH24 and $\mathrm{SH} 32$ ) were sufficiently resistant to $\mathrm{pH} 2.0$ for 2 to $6 \mathrm{~h}$ incubation periods. Only crude extracts of L. plantarum SH12 and L. plantarum SH24 were inhibitory against Lactococcus lactis B8, the strain used as indicator. The antibacterial activity of crude extracts was completely lost after treatment with $\alpha$ - chymotrypsin and proteinase K. L. plantarum $\mathrm{SH} 12$ and SH24 strains were susceptible to penicillin $\mathrm{G}$, oxacillin, vancomycin and clindamycin, but resistant to tetracycline and kanamycin. These strains showed rapid acidification activity (0.921 and $1.075 \mathrm{mmol} / \mathrm{l}$ of lactic acid, respectively), a good proteolytic activity $(5.45$ and $3.49 \mathrm{mg} / \mathrm{l}$ tyrosine at $72 \mathrm{~h}$, respectively) and high survival percentage after freeze-drying. None of the strains produced polysaccharides or haemolysin in sheep blood.

KEY-WORDS: Antibiotic - Bacteriocin - Butter - Lactic acid bacteria - Lactobacillus plantarum - Probiotics.

\section{INTRODUCTION}

Probiotics are live microbial food supplements which beneficially affect the host by improving the intestinal microbial balance (Tannock et al., 2000). Bacteria used as probiotic adjuncts are commonly delivered in a food system and, therefore, begin their journey to the lower intestinal tract via the mouth. As such, probiotic bacteria should have the ability to resist the digestion process in the stomach and the intestinal tract. Cellular stress begins in the stomach, which has a pH value as low as 1.5 to 2 (Lankaputhra and Shah, 1995). After the bacteria pass through the stomach, they enter the upper intestinal tract where bile is secreted into the gut. The concentration of bile in the human gastrointestinal system is variable and is difficult to predict at any given moment (Lankaputhra and Shah, 1995). After travelling through this harsh environment, the organism colonizes the epithelium of the lower intestinal tract (Conway et al., 1987). Thus, strains selected for use as probiotic bacteria should be able to tolerate acid and bile acids, attach to the epithelium, and grow in the lower intestinal tract before they can start providing any health benefits.

Lactic acid bacteria make up an extremely important group of probiotic bacteria and are already used in many probiotic dairy products (LourensHattingh et al., 2001). This group of bacteria is nonpathogenic, acid resistant; bile tolerant and produce 
antimicrobial substances, including, organic acids and hydrogen peroxide and bacteriocins (biologically active proteins) (Dunne et al., 1999). Among lactic acid bacteria, lactobacilli have been detected in diverse environments and are the subject of considerable research due to their commercial use in the food industry. They are used in the production of foods prepared by means of lactic acid fermentation (dairy products, fermented vegetables, fermented meats, and sourdough bread) (Hammes and Hertel, 2003). Furthermore, lactobacilli is considered to benefit the health of the consumer when ingested as probiotics.

Today, there is a growing need for new strains of lactic acid bacteria that carry the probiotic traits mentioned above and with favourable health effects on human and animals. This can be obtained from other natural ecological niches which remain unexploited. Camel milk is used therapeutically against dropsy, jaundice, problems of the spleen, tuberculosis, asthma, anaemia, and piles (Rao et al., 1970). Patients with chronic hepatitis had improved liver function after being treated with camel milk (Sharmanov et al., 1978). The camel milk works also as a laxative on people unaccustomed to drinking this milk (Rao et al., 1970).

In Algeria, camel milk represents an important food source (approximately 8000 tons are produced in arid and semi-arid areas, FAO, 2004). In these regions, camel milk is usually drunk immediately after milking. It can also be consumed as fermented milk made by natural lactic souring over several hours in a skin or clay container. The fermented milk may sometimes be separated by vigorous shaking; the acid skimmed milk is drunk and the butter (shmen) used for eating, cooking, cosmetic or medicinal purposes (Yagil, 1982). Shmen has played a major role in the diet of Touareg communities in the Sahara and today, there is a special demand for this product among consumers. The sensory profile of butter made from camel milk is conditioned by its very white colour, which probably results from a high amount of non-fat components such as proteins linked to the fat globules and considerable retention of buttermilk by capillary action (Farah et al., 1989 and Ramet, 1991). The flavor is neutral and unlike butter made from cow's milk. In a recent study, Kacem and Karam (2006a) have reported that $\mathrm{pH}$, titratable acidity and $\mathrm{NaCl}$ content of shmen produced in the Algerian Sahara varied according to the samples and regions. Microbiologically, L. plantarum was the major species of lactic acid bacteria isolated from this product. (Kacem and Karam, 2006a).

In the present study, L. plantarum strains isolated from the traditional butter (shmen) were investigated for bile, acidic $\mathrm{pH}$ values, freeze-drying and antibiotic resistance, as well as for bacteriocin and polysaccharide production, and acidifying, proteolytic and haemolytic activities. Our goal is the selection of potential probiotic strains through the development of starter cultures for manufacturing new probiotic butter from camel milk.

\section{MATERIALS AND METHODS}

\subsection{Bacterial strains and media}

L. plantarum strains used in this study (38 strains coded $\mathrm{SH} 1$ to $\mathrm{SH} 38$ ) were isolated from shmen (Kacem and Karam, 2006a). For antagonism assay, Lactococcus lactis B8 isolated from fermented olives (Kacem et al., 2005) was used as the indicator organism. They were maintained as a frozen stock at $-20{ }^{\circ} \mathrm{C}$ in distilled water plus $20 \%$ (v/v) glycerol and propagated twice in Man Rogosa Sharpe (MRS) broth (Oxoid Ltd., UK) (de Man et al., 1960) at $30{ }^{\circ} \mathrm{C}$ before use.

\subsection{Viable cells enumeration}

Viable cells were enumerated by plating diluted samples (peptonized water) on solid MRS agar (Oxoid Ltd., UK). Cultures were incubated for $48 \mathrm{~h}$ in anaerobic jars at $37^{\circ} \mathrm{C}$ to determine L. plantarum population. Bacterial growth was expressed in colony forming units per milliliter (cfu/ml) and the survival percentage $(\% \pm s d)$ of strains to different treatments was then calculated. Reported data are the means of duplicate analyses.

\subsection{Testing for bile and acidic $\mathrm{pH}$ values resistance}

The methods used to evaluate resistance strains to bile ( $2 \% \mathrm{w} / \mathrm{v}$ of oxgall: dehydrated fresh bile, Becton and Dickinson) and acidic $\mathrm{pH}$ values $(\mathrm{pH} \mathrm{1,2}$ and 3 for 2, 4 and $6 \mathrm{~h}$ ) were those described previously by Kacem and Karam (2006b). Growth was checked by spreading $100 \mu \mathrm{l}$ of cultures of appropriate dilutions onto MRS agar (Oxoid) (in order to standardize the assay, the initial culture was approximately $10^{6} \mathrm{cfu} / \mathrm{ml}$ ). Control cultures were without oxgall and cell counts were compared with those after $24 \mathrm{~h}$. The survival percentage (\% $\% \mathrm{sd}$ ) of strains to bile and different $\mathrm{pH}$ values was then calculated. The experiment was repeated twice and each reading represents the means of three observations. The strains with the best growth were considered to be acid and bile-tolerant and then used for further study.

\subsection{Testing for resistance to antibiotics}

Bacterial antibiotic resistance was determined on solid MRS medium with the use of 9 different antibiotic discs (bioMérieux, Marcy-l'Etoile, France) (Table 1). The results (average of 3 readings) were expressed as sensitive $(S)$ or resistant $(R)$ thanks to the standard disc diffusion method (National Committee for Clinical Laboratory Standards, 1999). Two strains with known antibiotic resistances (Staphylococcus aureus ATCC 25923 and Enterococcus faecalis ATCC 29212) were used as the control strains (Kacem and Karam, 2006b). 
Table 1

Antibiotic susceptibility and probiotic characteristics of two L. plantarum strains isolated from shmen.

\begin{tabular}{|c|c|c|}
\hline Test & L. plantarum SH12 & L. plantarum SH24 \\
\hline $\begin{array}{l}\text { Antibiotics } \\
\qquad \begin{array}{l}\text { Penicillin } \mathrm{G}(10 \mu \mathrm{g}) \\
\text { Oxacillin }(1 \mu \mathrm{g}) \\
\text { Vancomycin }(30 \mu \mathrm{g}) \\
\text { Cloramphenicol }(30 \mu \mathrm{g}) \\
\text { Clindamycin }(2 \mu \mathrm{g}) \\
\text { Rifampicin }(5 \mu \mathrm{g}) \\
\text { Tetracycline }(30 \mu \mathrm{g}) \\
\text { Kanamycin }(30 \mu \mathrm{g})\end{array}\end{array}$ & $\begin{array}{l}S \\
S \\
S \\
S \\
S \\
S \\
R \\
R\end{array}$ & $\begin{array}{l}S \\
S \\
S \\
S \\
S \\
S \\
R \\
R\end{array}$ \\
\hline $\begin{array}{l}\text { Survival percentage }(\% \pm \mathrm{sd}) \text { of strains } \\
\text { To bile }(2 \% \text { of oxgall) } \\
\text { At } \mathrm{pH} 2 \text { for } 2 \mathrm{~h} \\
\text { To freeze-drying }\end{array}$ & $\begin{array}{l}75 \pm 1.8 \\
54 \pm 0.8 \\
87 \pm 0.6\end{array}$ & $\begin{array}{l}65 \pm 1.6 \\
55 \pm 0.6 \\
86 \pm 0.7\end{array}$ \\
\hline Lactic acid production (mmol/l $\pm \mathrm{sd})$ & $0.921 \pm 0.29$ & $1.075 \pm 0.23$ \\
\hline Acidifying activity* & $(F)$ & $(\mathrm{M})$ \\
\hline Proteolytic activity (mg/l \pm sd tyrosine/72 h) & $5.45 \pm 0.21$ & $3.49 \pm 0.25$ \\
\hline Exopolysaccharide production & - & - \\
\hline Haemolytic activities & - & - \\
\hline Antagonistic activity & + & + \\
\hline Bacteriocin production & + & + \\
\hline
\end{tabular}

\subsection{Evaluation of acidifying, proteolytic and haemolytic activities of strains}

Acidification was measured by the change in $\mathrm{pH}$ $\left(\nabla \mathrm{pH}=\mathrm{pH}_{\mathrm{at} \text { time }}-\mathrm{pH}_{\text {zero time }}\right)$ during time according to the Lombardi et al. (2002) method. The acidification values were expressed as a decrease in $\mathrm{pH}$, calculated as the difference between the value immediately after inoculation and values at 0,2, 4 and $6 \mathrm{~h}(\nabla \mathrm{pH})$. The cultures were considered as fast, medium or slow acidifying when a $\Delta \mathrm{pH}$ of $0.4 \mathrm{U}(\mathrm{pH}$ units) was achieved after 3, 3-5 and $>5 \mathrm{~h}$, respectively.

Proteolytic activity of strains was determined in skim-milk medium (reconstituted skim milk powder $10 \% \mathrm{w} / \mathrm{v}$ ) by the tyrosine method (Hull, 1947), in accordance with the International Dairy Federation (IDF) standard 149A (1997). The results were expressed as $\mathrm{mg}$ tyrosine $\mathrm{I}^{-1}$ of milk.

Blood haemolysis was evaluated on Columbia agar plates (Oxoid) supplemented with 5\% sheep's blood which were incubated at $37^{\circ} \mathrm{C}$ for $24 \mathrm{~h}$ (Lombardi et al., 2004)

Production of lactic acid was measured using the precipitate method according to Pryce (1969) and expressed in $\mathrm{mmol} / \mathrm{l}$ after three replicates.

\subsection{Influence of freeze-drying}

Resistance of strains to freeze-drying was determined according to the Font de Valdez et al. (1985) method with minor modifications. Strains were grown in MRS broth(Oxoid) for $18 \mathrm{~h}$ at $37^{\circ} \mathrm{C}$, centrifuged (10000 g at $4^{\circ} \mathrm{C}$ for $10 \mathrm{~min}$ ), and then suspended to the initial volume in a cryoprotective solution containing $100 \mathrm{~g} / \mathrm{l}$ non-fat milk solids, $100 \mathrm{~g} / \mathrm{l}$ saccharose, and $4 \mathrm{~g} / \mathrm{l}$ ascorbic acid. The mixture was frozen at $-80{ }^{\circ} \mathrm{C}$ for $24 \mathrm{~h}$ and freeze-drying was then carried out at $-50^{\circ} \mathrm{C}$ for $48 \mathrm{~h}$ under 0.01 mbar vacuum (Model Lyph Lock 4.5, Labconco Corporation, Kansas City, MO, USA). Freeze-dried cultures were immediately rehydrated to their initial volume in MRS broth (Oxoid) for $10 \mathrm{~min}$ at $37^{\circ} \mathrm{C}$, and homogenized by high speed vortexing. Cell survival was then determined by the pour plate method.

\subsection{Polysaccharide production}

Exopolysaccharide production was evaluated as reported by Mora et al. (2002). Briefly, overnight cultures were streaked on the surface of plates containing ruthenium red milk $(10 \% \mathrm{w} / \mathrm{v}$, skim milk powder, $1 \% \mathrm{w} / \mathrm{v}$, sucrose and $0.08 \mathrm{~g} / \mathrm{l}$ ruthenium red, $1.5 \% \mathrm{w} / \mathrm{v}$ agar). After incubation at $37^{\circ} \mathrm{C}$ for $24 \mathrm{~h}$, 
non-ropy strains gave red colonies due to the staining of the bacterial cell wall, while ropy strains appeared as white colonies

\subsection{Detection of antagonistic activity of strains}

The antagonistic activity of strains was tested by the well diffusion method previously described by Schillinger and Lucke, 1989). Briefly, strains were propagated in $10 \mathrm{ml}$ MRS broth (Oxoid) for $24 \mathrm{~h}$ at $37^{\circ} \mathrm{C}$. The culture was centrifuged $(10,000 \mathrm{~g}$ for 20 min. at $4^{\circ} \mathrm{C}$ ) and the supernatant was adjusted to $\mathrm{pH} 7.0$ with $3 \mathrm{M} \mathrm{NaOH}$ to exclude the antimicrobial effect of $\mathrm{H}^{+}$, followed by filtration of the supernatant through a 0.22- $\mu$ m pore size filter (Gelman Acrodisc 13, Pall Corp., Ann Arbor, USA). Inhibitory activity from hydrogen peroxide was eliminated by the addition of $5 \mathrm{mg} / \mathrm{ml}$ catalase (C-100 bovine liver, Sigma). This solution was designated as the crude extract (CE). Pre-poured MRS agar plates were overlaid with $7 \mathrm{ml}$ MRS soft agar containing $0.2 \mathrm{ml}$ of indicator culture (Lactococcus lactis B8). In order to standardize the assay, the inoculum was approximately $10^{6}$ indicator cfu $\mathrm{ml}^{-1}$. Wells of $5 \mathrm{~mm}$ in diameter were cut into the agar plate using a cork borer, and aliquots of $50 \mu \mathrm{l}$ from each EC solution samples were placed into the wells. The plates were incubated under conditions suitable for bacterial growth, and examined for the presence of $1.5 \mathrm{~mm}$ or larger clear zones of inhibition around the wells. Each assay was performed in duplicate. The titers of antimicrobial agent in CE were quantified by the critical dilution method, as described by Schillinger and Lucke (1989). The antimicrobial activity of EC was defined as the reciprocal of the highest dilution showing inhibition of the indicator lawn and was expressed in arbitrary units per $\mathrm{ml}(\mathrm{AU} / \mathrm{ml})$.

\subsection{Characterization of the antimicrobial agent}

Samples of CE were examined for susceptibility to proteolytic enzymes. The following enzymes (1 $\mathrm{mg} / \mathrm{ml}$ ) and respective buffers were used: pronase $\mathrm{E}$, trypsin, $\alpha$-chymotrypsin in $0.01 \mathrm{mM}$ sodium phosphate ( $\mathrm{pH} 7$ ); proteinase $\mathrm{K}$ in $0.1 \mathrm{mM}$ sodium acetate, $0.005 \mathrm{mM}$ calcium acetate $(\mathrm{pH} 7.5) ; \alpha-$ amylase in $0.01 \mathrm{mM}$ potassium sulphate $(\mathrm{pH} \mathrm{7})$ and lipase in $0.1 \mathrm{mM}$ potassium sulphate $(\mathrm{pH} \mathrm{6)}$. All enzymes were obtained from Sigma (Chemical Company, St. Louis, Mo, USA) except trypsin and lipase which were from Serva (Gmbh, Heidelberg, Germany). The CE was mixed with equal volumes of enzymatic solutions and incubated at $30{ }^{\circ} \mathrm{C}$ for 1 $\mathrm{h}$, after which the remaining activity was determined by the agar diffusion method described previously. As a control, CE with added respective buffer solution was treated in the same manner as the test preparation.

Samples of CE were adjusted to $\mathrm{pH}$ values in the range of $1-12$ using $3 \mathrm{~N} \mathrm{HCl}$ or $3 \mathrm{~N} \mathrm{NaOH}$. Af- ter storage at $4{ }^{\circ} \mathrm{C}$ for $24 \mathrm{~h}$, the samples were neutralized and the remaining antimicrobial activities were tested by the well diffusion method.

Aliquots of $\mathrm{CE}$ were subjected to different heat treatments, at $60^{\circ} \mathrm{C}$ and $80^{\circ} \mathrm{C}$ (in a water bath) and at $121^{\circ} \mathrm{C}$ (autoclave) for $15 \mathrm{~min}$. The remaining antimicrobial activity was determined by the well diffusion method. Finally, sterile CE was stored at $25^{\circ}$, $4^{\circ},-20^{\circ}$ and $-30^{\circ} \mathrm{C}$. At different time intervals, samples were taken from the stored material for determination of the remaining activity.

From inhibitory assays conducted with the sensitive strain (Lactococcus lactis B8), samples were taken from inhibition zones (the clear surface of agar) and streaked onto fresh medium agar plates and incubated for $48 \mathrm{~h}$ at $30{ }^{\circ} \mathrm{C}$. Growth or no growth was recorded as the difference between the bacteriostatic and bactericidal activity of CE (Toba et al., 1991).

\section{RESULTS}

Among 38 L. plantarum strains investigated for bile resistance, 14 showed high tolerance to $2 \%$ of oxgall with survival percentages ranging from $75 \pm$ 1.8 to $69 \pm 2.1 \%$ ). The other strains (24 strains) showed low survival percentages (04 \pm 1.7 and 09 $\pm 2.1 \%$ ). Strains which showed resistance to bile were tested afterwards for resistance to different acidic $\mathrm{pH}$ values. At $\mathrm{pH} 2.0,4$ strains among the 14 tested showed high survival percentages (71 to $54 \%, 44$ to $32 \%$ and 28 to $21 \%$ ) after 2,4 and $6 \mathrm{~h}$ incubation, respectively, with a decrease in survival percentage when the exposure time progresses for strains. All tested strains survived an incubation period of $2 \mathrm{~h}$ to $6 \mathrm{~h}$ at $\mathrm{pH} 3.0$, but no growth occurred after incubation at $\mathrm{pH} 1$ for $2 \mathrm{~h}$. Strains (L. plantarum SH5, SH12, SH24 and SH32) which survived acidic conditions (at $\mathrm{pH} 2.0$ ) better than the rest of the strains were then screened for their antagonistic activity using the well diffusion method.

Only crude extracts of L. plantarum SH12 (CE1), and $L$. plantarum SH24 (CE2) were inhibitory against the sensitive Lactococcus lactis B8 strain tested (Figure 1). The titter of CE1 and CE2 was found to be 800 and $1600 \mathrm{AU} / \mathrm{ml}$ respectively. As described in Materials and Methods, samples were taken from inhibition zones and surface streaked to medium agar plates. After incubation of the plates, no bacteria growth was observed. This result suggests that CE1 and CE2 are bactericidal toward Lactococcus lactis B8.

In an attempt to characterize the inhibitory agent, the crude extract (CE) samples from L. plantarum SH12 (CE1) and L. plantarum SH24 (CE2) were treated with different chemical and physical agents as describe above. Activity was completely inactivated by $\alpha$-chymotrypsin and proteinase $\mathrm{K}$ but partially inactivated after treatment with trypsin and pronase $E$ which reflects the proteinaceous nature of the inhibitory agent. The fact that the inhibitory compound was not inactivated by treatment 


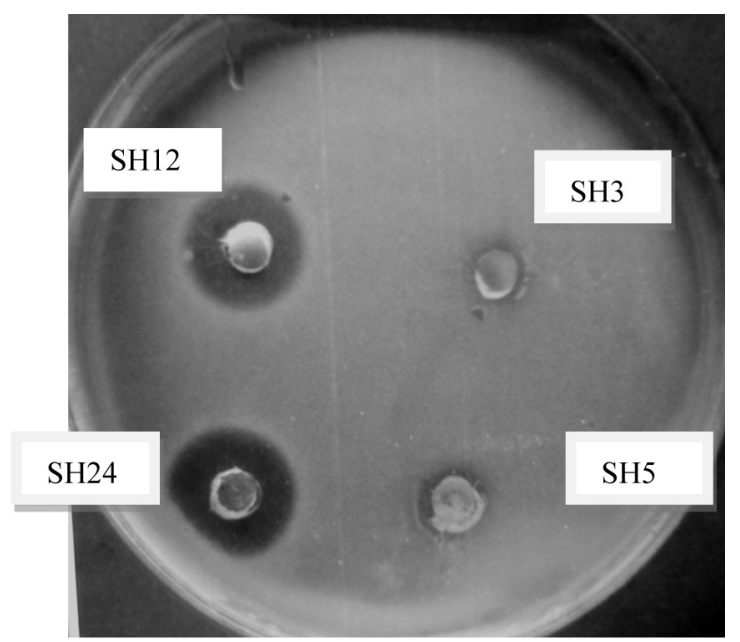

Figure 1.

Agar well diffusion assay showing the antibacterial activity of cell-free supernatants from L. plantarum SH5, SH12, SH24, and SH32. Lactococcus lactis B8 was used as the indicator strain.

with lipase or $\alpha$-amylase suggests that activity was not dependent on the presence of either a carbohydrate or lipid moiety. Furthermore, we have established that ECs are bactericidal towards the sensitive strain tested. From these findings, and in accordance with the guidelines outlined by Klaenhammer (1988), the proteinaceous antibacterial substances can be attributed to bacteriocin-like substances.

Inhibitory activity of this proteinaceous substance was stable at $80^{\circ} \mathrm{C}$ and at $121^{\circ} \mathrm{C}$ for $15 \mathrm{~min}$. Also, it was observed that CEs could be stored at $-20^{\circ}$ and $-30{ }^{\circ} \mathrm{C}$ for at least 2 or 3 months without loss of activity. No activity was detected after storage for 80 to 120 days at $37^{\circ} \mathrm{C}$. Inhibitory activity was also stable at $\mathrm{pH} 2$ to 6 but was completely inactivated after exposure to $\mathrm{pH} 8$.

L. plantarum SH12 and SH24 strains which showed acid-and bile tolerance and antagonistic activity were then examined for their antibiotics susceptibility, lactic acid and exopolysaccharide production, acidifying, proteolytic and haemolytic activities. Results are summarized in Table 1. Strains tested were susceptible to penicillin G, oxacillin, vancomycin and clindamycin, but resistant to tetracycline and kanamycin. L. plantarum SH12 and $\mathrm{SH} 24$ were fast acidifying strains and produced $0.921 \pm 0.29$ and $1.075 \pm 0.23 \mathrm{mmol} / \mathrm{l} \pm \mathrm{sd}$ of lactic acid, respectively. L. plantarum SH12 strain showed the highest activity (5.45 $\pm 0.21 \mathrm{mg} / \mathrm{l}$ tyrosine) while, L. plantarum $\mathrm{SH} 24$ strain showed the lowest (3.49 $\pm 0.25 \mathrm{mg} / \mathrm{l}$ tyrosine).

Strains were frozen at $-80^{\circ} \mathrm{C}$, freeze-dried at $-50{ }^{\circ} \mathrm{C}$ for $48 \mathrm{~h}$, thawed within $10 \mathrm{~min}$ at $37^{\circ} \mathrm{C}$ and then regrown on MRS broth. Results indicated that the two strains readily grew in MRS agar after freeze-drying and showed high survival percentages to freeze-drying (up to $86 \pm$ sd \%) (Table 1). None of the strains produced exopolysaccharides or haemolysin on sheep's blood.

\section{DISCUSSION}

In this study, four acid and bile tolerant strains were obtained after exposing 38 strains of L. plantarum to $2 \%$ of oxgall and $\mathrm{pH} 2$ for $6 \mathrm{~h}$. Similar results were reported by Dunne et al. (2001) and ElNaggar (2004). However, these results may not reflect exactly the number of bile-tolerant strains selected because the $2 \%$ oxgall used for testing our strains represents the extreme concentration obtained in the intestine of an animal or human during the first hour of digestion (Gotcheva et al., 2002). Afterwards the normal level of bile salt in the intestine is around $0.3 \%$. At the same time, resistance to bile salts varies a lot among the lactic acid bacteria species and even between strains themselves (Xanthopoulos, 1997). Only two (L. plantarum SH12 and $\mathrm{SH}_{24}$ ) were found to produce an active agent in a liquid medium when tested by the well diffusion method. These results have also been reported by Geis et al.. (1983), Klaenhammer (1988) and Kacem et al. (2005). The bactericidal effect of $L$. plantarum $\mathrm{SH} 12$ or $\mathrm{SH} 24$ on the sensitive Lactococcus lactis B8 strain tested exhibited properties similar to those of the bacteriocins of several other lactic acid bacteria (Delgado et al., 2001, Maldonado et al., 2003, Kacem et al., 2005).

Results indicated that $L$. plantarum strains were tetracycline resistant which is in accordance with other reported studies (Halami et al., 2000 and Coppola et al., 2005). All strains tested were sensitive to vancomycin. This result does not confirm the finding of Salminen et al. (1998) who reported that vancomycin resistance is an intrinsic property of lactobacilli. All strains showed fast or medium acidification activity which differs from those reported by Ayad et al. (2004) who indicated that most strains of L. plantarum isolated from different sources showed a slow acidification rate.

Proteolysis is required by lactic acid bacteria for fast growth and acid production in milk fermentations (Thomas and Pritchard, 1987). Probiotic bacteria are often delivered in dairy products and must maintain their population during shelf-life; presumably, protease activity is important in this respect. In this study, strains have shown good proteolysis $(5.45 \pm 0.21$ and $3.49 \pm 0.25 \mathrm{mg} / \mathrm{l}$ tyrosine $)$. Similar results were obtained by other authors (Usman and Hosono, 1999 and El-Naggar, 2004).

In addition, a better cell survival to freeze-drying conditions was observed for the strains tested. This is an essential characteristic for the selection of probiotic bacteria because the mode of delivery is often in frozen dairy desserts. This characteristic is also critical for the storage of frozen stock cultures used in industrial production

\section{CONCLUSION}

Consumers are becoming more and more interested in foods that have a health benefit beyond basic nutrition and the food industry is trying to ful- 
fill these demands by developing products with measurable health benefits. Foods that contain probiotics are part of these and are gaining consumer interest. Current research in our laboratory is aimed at developing and incorporating our selected strains (L. plantarum SH12 and SH24) as starter cultures for camel milk fermentation. This would allow us to produce a new probiotic dairy product from camel milk such as fermented milk, butter or cheese with flavor and sensorial qualities desired by tasters. Camel dairy products can certainly play a far more important role in the prevention of malnutrition than it does today.

\section{ACKNOWLEDGEMENTS}

This study was supported by a grant of the "Ministère de l'Enseignement Supérieur" of Algeria and a grant of ANDRS.

\section{REFERENCES}

Ayad EHE, Nashat S, El-Sadek N, Metwaly H, El-Soda M. 2004. Selection of wild lactic acid bacteria isolated from traditional Egyptian dairy products according to production and technological criteria. Food Microbiol. 21, 715-725.

Conway PL, Gorbach SL, Golden BR. 1987. Survival of lactic acid bacteria in the human stomach and adhesion to intestinal cells. J. Dairy Sci. 70, 1-12.

Coppola R, Succi M, Tremonte P, Reale A, Salzano G, Sorrentino E. 2005. Antibiotic susceptibility of $L$. rhamnosus strains isolated from Parmigiano Reggiano cheese. Lait 85, 193-204.

de Man JC, Rogosa M, Sharpe EM. 1960. A medium for the cultivation of lactobacilli. J. Appl. Bacteriol. 23, 130-135.

Delgado A, Brito D, Fevereiro P, Marques JF. 2001. Antimicrobial activity of $L$. plantarum, isolated from a traditional lactic acid fermentation of table olives. Lait $\mathbf{8 1}$, 203-215.

Dunne C, Murphy L, Flynn S, O'Mahony L, O'Halloran S, Feeney M, Morrissey D, Thornton G, Fitzgerald G, Daly C, Kiely B, Quigley E MM, O'Sullivan GC, Shanahan F, Kevin J. 1999. Probiotics: from myth to reality. Demonstration of functionality in animal models of disease and in human clinical trials. Antonie van Leeuwenhoek 76, 279-292.

Dunne C, O'Mahony L, Murphy L, Thornton G, Morrissey D, O'Halloran S, Feeney M, Flynn S, Fitzgerald G, Daly C, Kiely B, O'Sullivan GC, Shanahan F,. Collins JK. 2001. In vitro selection criteria for probiotic bacteria of human origin: correlation with in vivo findings. Am. J. Clin. Nutr. 73 (suppl), 386S-392S.

El-Naggar MYM. 2004. Comparative study of Probiotic cultures to control the growth of E. coli O157:H7 and Salmonella tybhimurium. Biotechnology 3, 173-180.

FAO. 2003. Production et santé animales. Lait de Chamelle pour l'Afrique. Niamey, 5 - 8 Novembre.

Farah Z, Streiff T, Bachmann MR. 1989. Manufacture and characterization of camel milk butter. Milchwissenschaft 44, 412-414.

Font de Valdez G, Savoy de Giori G, Pesce de Ruiz Holgado AA, Oliver G. 1985. Effect of the rehydration me- dium on the recovery of freeze-dried lactic acid bacteria. Appl. Environ. Microbiol. 50, 1339-1341.

Geis A, Singh J, Teuber M. 1983. Potential of lactic streptococci to produce bacteriocin. Appl. Environ. Microbiol. 45, 205-211.

Gotcheva V, Hristozova E, Hristozova T, Guo M, Roshkova Z, Angelov A. 2002. Assessment of potential probiotic properties of lactic acid bacteria and yeast strains. Food Biotechnol. 16, 211-225.

Halami PM, Chandrashekar A, Nand K. 2000. LactobaciIlus farciminis MD, a newer strain with potential for bacteriocin and antibiotic assay. Letters Appl. Microbiol. 30, 197-202.

Hammes WP, Hertel C. 2003. The genera Lactobacillus and Carnobacterium, in Dworkin M et al. (Eds.) The Prokaryotes: An evolving electronic resource for the microbiological community. Release 3.15. SpringerVerlag, New York, http://link.springer-ny.com/link/service/books/10125/.

Hull ME. 1947. Studies of milk proteins. Colorimetric determination of the partial hydrolysis of the proteins in milk. J. Dairy Sci. 30, 881.

IDF (International Dairy Federation) standard 149A. 1997. Levains lactiques de cultures de bacteries lactiques. Norme de composition. IDF Standard 149A. Brussels, Belgium.

Kacem M, Karam NE. 2006a. Physicochemical and microbiological study of "shmen", a traditional butter made from camel milk in the Sahara (Algeria): isolation and identification of lactic acid bacteria and yeasts. Grasas y Aceites 57 (2) 198-204.

Kacem M, Karam NE. 2006b. In vitro preselection criteria for probiotic Lactobacillus plantarum strains of fermented olives origin. Int. J. Probiotics Prebiotics (in press).

Kacem M, Zadi-Karam H, Karam N. 2005. Detection and activity of plantaricin OL15, a bacteriocin produced by Lactobacillus plantarum isolated from Algerian fermented olives. Grasas y Aceites 56, 192-197.

Klaenhammer TR. 1988. Bacteriocins of lactic acid bacteria. Biochimie 70, 337-349.

Lankaputhra WEV, Shah NP. 1995. Survival of LactobaciIlus acidophilus and Bifidobacterium spp in the presence of acid and bile salts. Cultured Dairy Prod. J. $30,2-7$.

Lombardi A, Dal Maistro L, De Dea P, Gatti M, Giraffa G, Neviani E. 2002. A polyphasic approach to highlight genotypic and phenotypic diversities of Lactobacillus helveticus strains isolated from diary starter cultures and cheeses. J. Dairy Res. 69, 139-149.

Lourens-Hattingh A, Viljoen BC. 2001. Yogurt as probiotic carrier food. Int. Dairy J. 11, 1-17.

Maldonado A, Ruiz-Barba JL, Jiménez-Díaz R. 2003. Production of plantaricin NC8 by Lactobacillus plantarum NC8 is induced in the presence of different types of gram positive bacteria. Arch. Microbiol. 181, 8-16.

Mora D, Fortina MG, Parini C, Ricci G, Gatti M, Giraffa G, Manachini PL. 2002. Genetic diversity and technological properties of Streptococcus thermophilus strains isolated from dairy products. J. Appl. Microbiol. 93, 278-287.

NCCLS (National Committee for Clinical Laboratory Standards). 1999. NCCLS document M-100-S9. Performance Standards for antimicrobial susceptibility testing. 9 th. information supplement. NCCLS, Wayne, PA.

Pryce JD. 1969. A modification of the Barker-Summerson method for the determination of lactic acid. Analyst 94, 1151-1152. 
Ramet JP. 1991. La transformation en fromages de lait de dromadaire. World Animal Rev. 67, 20-28.

Rao MB, Gupta RC, Dastur NN. 1970. Camels' milk and milk products. Ind. J. Dairy Sci. 23, 71-78,

Salminen S, Wright A, Morelli L, Marteau P, Brassart D, de Vos WM, Fonden R, Saxelin M, Collins K, Mogensen G, Birkeland S-E, Mattila-Sandholm T. 1998. Demonstration of safety of probiotics, a review. Int. J. Food Microbiol. 44, 93-106.

Schillinger U, Lücke FK. 1989. Antibacterial activity of $L$. sake isolated from meat. Appl. Environ. Microbiol. 55, 1901-1906.

Tannock GW, Munro K, Harmsen HJ, Welling GW, Smart J, Gopal PK. 2000. Analysis of the fecal microflora of human subjects consuming a probiotic product containing Lactobacillus rhamnosus DR20. Appl. Environ. Microbiol. 66, 2578-2588.

Thomas TD, Pritchard GG. 1987. Proteolytic enzymes of dairy starter cultures. FEMS Microbiol. Rev. 46, 245-268.
Toba T, Samant SK, Yoshioka E, Itoh T. 1991. Reutericin 6, a new bacteriocin produced by Lactobacillus reuteri LA 6. Letters Appl. Microbiol. 13, 281-286.

Usman M, Hosono A. 1999. Bile tolerance taurocholate desegregation and binding of cholesterol by Lactobacillus gasseri strain. J. Appl. Sci. 82, 243-248.

Xanthopoulos V, Litopoulou-Tzanetaki E, Tzanetakis N. 1997. In vitro study of Lactobacillus species strains on bile tolerance and cholesterol removal, in Lactic Acid Bacteria - Lactic 97. Caen, Presses Universitaires de Caen.

Yagil R. 1982. Camels and camel milk, in FAO Animal Production and Health Paper, no. 26. FAO, Rome.

Sharmanov TSh, Kadyrova RKh, Shlygina OE, Zhaksylykova RD. 1978. Changes in the indicators of radioactive isotope studies of the liver of patients with chronic hepatitis during treatment with whole camels' and mares' milk. Voprosy Pitaniya 1, 9-13.

Recibido: $28 / 9 / 07$

Aceptado: $23 / 1 / 08$ 